\title{
Histopathological and Enzymatic Changes in Liver of Mice Treated with Tricyclazole
}

Esmail Fattahi (PhD)

Department of Biology, Islamic Azad University, Ayatollah Amoli branch, Amol, Iran

Corresponding author: Esmail Fattahi

Address: Department of Biology, Islamic Azad University, Ayatollah Amoli branch, Amol, P.O.X 678, Iran Tel: +9843217320

Email: esmail_fattahy@yahoo.com Address: Islamic Azad University, Ayatollah Amoli branch, Amol, Iran

Received : 14 Aug 2016

Revised: 01 Nov 2016

Accepted: 07 Nov 2016
ABSTRACT

Background and objectives: Tricyclazole (TCZ) is a member of triazole fungicides, which might cause damage in living systems. This study was carried out to examine effects of TCZ on liver tissues and level of liver enzymes.

Methods: Forty mice were randomly divided into four groups including control, sham and two experimental groups. Experimental groups 1 and 2 received $5 \mathrm{mg} / \mathrm{Kg}$ and 15 $\mathrm{mg} / \mathrm{Kg}$ intraperitoneal injection of TCZ for two weeks, respectively. The sham group received sterile water but the control group received no injection. The animals were sacrificed $24 \mathrm{~h}$ after the last injection, and microscopic slides were prepared for cell counting and evaluation of tissue damage. Levels of liver enzymes were measured using commercial kits. Data was analyzed in SPSS (version 20) using one-way ANOVA.

Results: The injection of TCZ caused a significant increase in the number of hepatocytes and a significant decrease in the number of Kupffer cells compared to control group $(\mathrm{P}<0.001)$. In the experimental group, the level of alanine aminotransferase and aspartate aminotransferase increased, but the level of alkaline phosphatase decreased significantly compared to control group $(\mathrm{P}<0.001)$. We also detected several forms of tissue damage including necrosis and degeneration of hepatocytes, hyperplasia, and penetration of inflammatory cells and expansion of sinusoids.

Conclusion: 0ur results indicate that the intraperitoneal injection of TCZ in mice can cause irreparable hepatic damage in a dose-dependent manner.

Keywords: Tricyclazole, hepatocytes, Alanine, Aspartate aminotransferase. 


\section{INTRODUCTION}

Widespread application of toxins can cause teratogenic effects on various growthrelated phenomena, which has raised concerns about the potential damages that pesticides can inflict on human health and the ecosystem (1). Tricyclazole (TCZ) is one of the most commonly used pesticides, particularly in Asian countries. This systemic fungicide belongs to the triazole group, and used to eradicate rice blast $(2,3)$. This toxin can remain active in soil and water after long-term use. Exposure to the toxin can cause several health-related problems (4). Toxins are readily absorbed by skin and converted to secondary metabolites in the liver. A large amount of these metabolites are excreted by the kidneys, but the remaining may cause tissue damage in the body (5). Toxicity of TCZ in various organs including the reproductive system and liver and the potential biochemical and tissue changes have been reported $(6,7)$. Some reports indicate that triazoles can affect liver enzymes, particularly cytochromes. Although the precise mechanism of action of TCZ in the body has not been determined, some scientists believe that this toxin promotes lipid peroxidation and cell death by inducing production of free radicals and reactive oxygen species (8). Studies on liver tissues of prenatal mice showed that triazoles increase the number of hepatocytes and concentration of alanine transaminase (ALT) and aspartate aminotransferase (AST), but reduce the activity of alkaline phosphatase (ALP). In addition, some studies demonstrated that TCZ significantly increases the activity of ALP and ALT in fish $(9,10)$. As the largest gland in the body, liver has several important functions including neutralization of toxins, drugs and other harmful compounds. Detoxification and metabolic activation by liver enzymes usually produce toxic metabolites that cause toxic damage, necrosis and acute liver failure (11). Despite the widespread use of TCZ in recent years, little information is available about acute hepatotoxicity in Iran. Therefore, the present study has examined effects of TCZ on histopathology of liver and level of liver enzymes.

\section{MATERIAL AND METHODS}

In this experimental-analytical study, we purchased 40 adult NMRI mice aged two months (average weight $30 \pm 5 \mathrm{~g}$ ) from the
Pasteur Institute (experimental Animal keeping center, Iran). The animals were kept in special cages at $23 \pm 2{ }^{\circ} \mathrm{C}$ and $12: 12 \mathrm{~h}$ light/dark cycle. The animals were given ad libitum access to food and water. The study was in accordance with ethical standards for handling animals set by the Ethics Committee of Islamic Azad University (No: 7812). From the stock solution of TCZ 95\% (Gol Sam Co, Gorgan, Iran), various concentrations of the toxin were prepared in sterile water and then injected to the animals on a daily basis and at a specific time. The animals were randomly divided into four equal groups $(n=10)$. Control group received no TCZ and sham group received sterile water injections for two weeks. Experimental group 1 received $5 \mathrm{mg} / \mathrm{Kg}$ intraperitoneal injection of TCZ for two weeks (5 days a week, while resting for two days). Experimental group 2 received $15 \mathrm{mg} / \mathrm{Kg}$ intraperitoneal injection of TCZ for two weeks (5 days a week, while resting for two days)[12]. All animals were kept under optimum conditions. Twenty-four hours after receiving the last injection, the animals were sacrificed and sampling was done. Blood samples were taken from heart to measure levels of ALT, AST and ALP. The samples were then centrifuged at $3000 \mathrm{rpm}$ for $15 \mathrm{~min}$ to separate serum. Next, the level of each enzyme was measured using Hitachi 911(Taiwan) full automated analyzer and Pars Azmoon kits (Iran). The mice were dissected and liver tissues were isolated. The tissues were fixed in $10 \%$ formalin. After routine steps of tissue preparation, paraffinized tissue blocks were retrieved and used to prepare 5micron serial sections stained with hematoxylin-eosin. The sections were selected in a way that almost 100 sections from each part of the liver could be evaluated. Cell counting for hepatocytes and Kupffer cells was carried out with three repeats using eyepiece graticules. The data was analyzed in SPSS (version 20) using one-way ANOVA and posthoc Tukey to compare means between the groups. P-values less than 0.05 were considered as statistically significant.

\section{RESULTS}

The number of hepatocytes in the experimental groups reduced significantly compared to the control group, but the number of Kupffer cells increased significantly in the experimental 
groups (Table 1). No significant difference was found between the Sham and Control groups. Our results indicated that cell number changes in experimental group 2 were more evident than those in experimental group 1.

Biochemical analysis indicated that serum level of ALT and AST increased significantly following the intraperitoneal injection of 5 and $15 \mathrm{mg} / \mathrm{Kg}$ TCZ. However, ALP reduced significantly in TCZ-treated mice compared to controls (Table 1). No change occurred in the level of liver enzymes in the control and sham groups. Microscopic examination of the liver tissues from mice treated with $5 \mathrm{mg} / \mathrm{Kg} \mathrm{TCZ}$
(Experimental group 1) showed signs of necrosis, degeneration, and irregular hepatocyte layers, penetration of inflammatory cells, liver fibrosis and expansion of sinusoids when compared to controls. In experimental group 2, liver damages were more extensive including hepatocytes necrosis and degeneration, triad fibrosis, necrosis of parenchymal liver cells and bile duct hyperplasia. The number of Kupffer cells in experimental group 2 was higher than that in experimental group 1, which could be due to the higher dose of TCZ administered (Figure $1)$.

Table 1- Mean levels of liver enzvmes and the number of hepatocvtes and Kupffer cells in each studv group

\begin{tabular}{|c|c|c|c|c|}
\hline Parameters & Control group & Sham group & $\begin{array}{c}\text { Experimental group } \\
1(5 \mathrm{mg} / \mathrm{kg})\end{array}$ & $\begin{array}{c}\text { Experimental group } 2 \\
(15 \mathrm{mg} / \mathrm{kg})\end{array}$ \\
\hline Number of hepatocyte & $57.68 \pm 4.6^{\mathrm{a}}$ & $56.36 \pm 4.2^{\mathrm{a}}$ & $49.38 \pm 3.4^{b}$ & $45.86 \pm 5^{c}$ \\
\hline Number of Kupffer cells & $5.38 \pm 2.45^{c}$ & $5.66 \pm 2.87^{c}$ & $8.26 \pm 3.08^{b}$ & $9.73 \pm 2.96^{\mathrm{a}}$ \\
\hline $\operatorname{AST}(\mathbf{I U} / \mathbf{L})$ & $165.5 \pm 18.4^{\mathrm{c}}$ & $172.9 \pm 22^{c}$ & $435 \pm 25^{b}$ & $526 \pm 24^{\mathrm{a}}$ \\
\hline ALT(IU/L) & $73 \pm 11^{c}$ & $82 \pm 19^{c}$ & $152 \pm 17^{b}$ & $262 \pm 26^{a}$ \\
\hline $\mathbf{A L P}(\mathbf{I U} / \mathbf{L})$ & $323 \pm 31.4^{\mathrm{a}}$ & $315 \pm 28.3^{\mathrm{a}}$ & $219.6 \pm 38.36^{b}$ & $193.5 \pm 31^{\mathrm{c}}$ \\
\hline \multicolumn{5}{|c|}{$\begin{array}{l}\text { Data shown as mean } \pm \text { SE. In each row, there are mean values that have at least one letter in common; these mean values are not } \\
\text { significantly different at } 5 \% \text { in Duncan test. }\end{array}$} \\
\hline
\end{tabular}

Figure 1- Photomicrograph of mouse liver tissue stained with hematoxylin and eosin
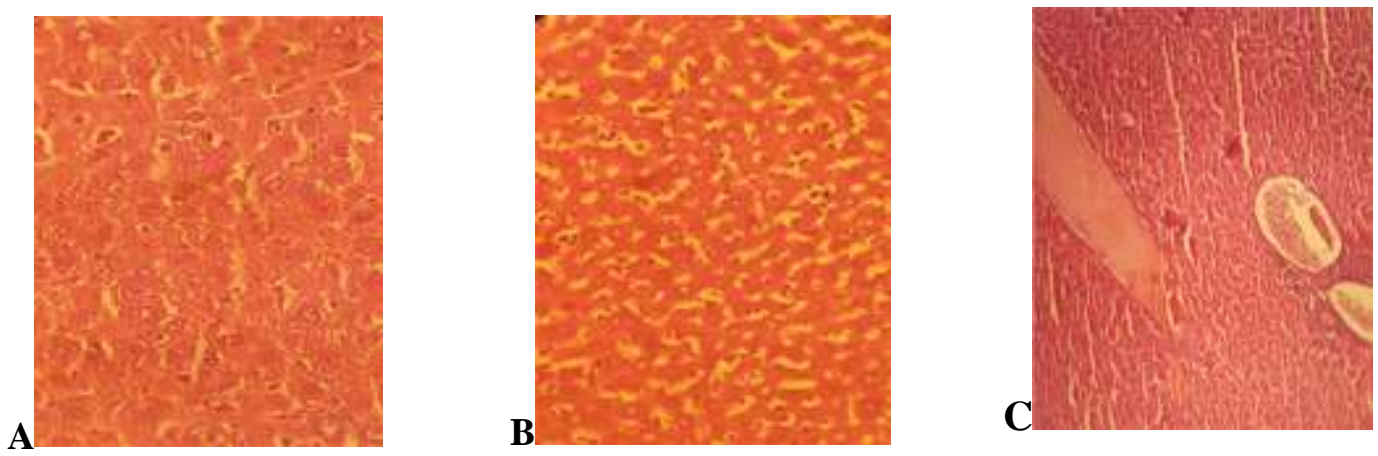

(A): Normal tissue in control group (X400), (B): Effect of TCZ administration via penetration of inflammatory mononuclear cells (purple arrow), vacuolation in hepatocytes (green arrow) and Kupffer cells (black arrow) (X200), (C): Expansion of blood vessels following TCZ injection (X100).

\section{DISCUSSION}

In our study, TCZ injection reduced the number of hepatocytes but increased the number of Kupffer cells compared with controls. The level of ALT and AST in TCZ-treated groups increased significantly compared with controls. However, the level of ALP in the experimental groups reduced significantly. TCZ injection also caused damages including necrosis, hepatocyte degeneration, triad fibrosis, bile duct hyperplasia, penetration of mononuclear cells, and sinusoid expansion. These effects were more severe in mice treated with higher doses of TCZ.

Although TCZ is converted to active metabolites in the liver, but the activity of liver against these compounds is limited. Thus, exposure to large amounts of this toxin may cause toxic damage, necrosis and acute liver 
failure (11). Previous studies demonstrated that triazoles damage the liver by changing the activity of liver enzymes. Liver enzymes such as ALT, AST and ALP specifically reflect hepatocytes necrosis, and are used for detection of severe liver diseases such as liver inflammation $(11,13,14)$. In animals such as rats, ALT is confined to hepatocytes and increases in the bloodstream immediately after a change in liver activity (13). In addition, AST has been recommended for diagnosis of liver failure. In this study, the level of ALT and AST increased in the experimental groups, which could indicate liver tissue degeneration caused by cell membrane damage and necrosis (7). These findings are in line with some previous studies $(6,7)$. We also found that TCZ injection reduced the level of ALP, which is a biochemical marker for bone and liverbiliary disorders as well as lapidated liver (15, 16). Some studies reported that triazoles reduce ALP levels $(6,12)$, while others claimed the opposite $(17,18)$. The reduced level of ALP may be caused by bile duct hyperplasia observed in histopathological examination of our TCZ-treated samples. We also found that the number of hepatocytes reduced in the experimental groups compared to the controls. Some experts claim that triazoles generate free radicals and oxygen reactive species that reacts with lipids, proteins and nucleic acids thereby breaking chemical bonds and inducing cell death (8).

\section{REFERENCES}

1.Fattahi E, Parivar K, Jorsaraei SGA, MoghadamniaAA. The effects of diazinon on testosterone, FSH and LH levels and testicular tissue in mice. Iran J Reprod Med. 2009; 7(2): 59-64.

2.Padovani L, Capri E, Padovani C, Trevisan M. Monitoring tricyclazole residues in rice paddy watersheds. Chemosphere. 2006; 62(2): 303-14.

3.Kunova A, Pizzatti C, Cortesi P. Impact of tricyclazole and azoxystrobin on growth, sporulation and secondary infection of the rice blast fungus.Magnaportheoryzae. Pest Manag Sci. 2013; 69(2): 278-84. doi: 10.1002/ps.3386.

4.Jeong SA, Thapa SP, Park HR, Choi NG, HurJH. Distribution and persistence of tricyaclazole in agricultural field soils. Bull Environ ContamToxicol. 2012; 89(6): 1181-5. doi: 10.1007/s00128-012-0800-y.

5. Fattahi E, Jorsaraei SGA, Gardaneh M. The effect of Carbaryl on the pituitary-gonad axis in male rats. Iran $\mathrm{J}$ Reprod Med. 2012; 10(5): 419-24.

6.Rowshanaie T, Sadoughi M, FattahiE.The Effects of Tricyclazole on HepaticEnzyme Changes and Tissue Damage in the Fetus of Laboratory Mice. J BabolUniv Med Sci. 2015; 17(7): 51-7.
The histopathological changes in liver tissue following TCZ administration can be an important sign of liver degeneration, which in turn increases the release of AST and ALT. The number of Kupffer cells increased after TCZ injection.

In fact, these cells are mature macrophages in liver sinusoids, and the increased number of Kupffer cells for digestion of necrotic cells after TCZ injection could be attributed to their phagocytosic role (6).

\section{CONCLUSION}

Our results indicate that the intraperitoneal injection of TCZ in mice can cause irreparable hepatic damage in a dose-dependent manner. Considering the widespread use of TCZ as fungicide in farms and the results obtained in our study, it is recommended to accurately monitor and control the amount and duration of the toxin's application.

\section{ACKNOWLEDGEMENTS}

We are grateful to the Research Deputy of Islamic Azad University, Ayatollah Amoli branch for the financial support. We also thank all individuals who contributed to this study.

\section{CONFLICT OF INTEREST}

None declared.

7.Sancho E, Cristina F, Ma JV, Andreu-Moliner E, FerrandoMA. Physiological effects of tricyclazole on zebrafish (Daniorerio) andpost-exposure recovery. CompBiochemPhysiol C ToxicolPharmacol. 2009; 150(1): 25-32. doi: 10.1016/j.cbpc.2009.02.004.

8.Bagchi D, Bagchi M, Hassoun EA, Stohs SJ. In vitro and in vivo generation of reactive oxygen species, DNA damage and lactate dehydrogenase leakage by selected pesticides. Toxicology. 1995; 104(1-3): 129-140.

9.Vivek S, Indumathi SP, Radha T. Ecological Risk Assesment of the Fungicide Tricyclazole $75 \%$ ) on Ophiocephalusleucopunctatus (Sykes, 1839) with Respect to Hepatic Enzymes and Pathological Anamolies. Res J AgricBiol Sci. 2009; 5(4): 445.

10.Magbooljan Noornissabegum R. Liver or hepatic enzyme activity in fresh water fish Oreochromismossambicusexposedtotricyclazole fungicide. J Toxicol Heal. 2013; 103: 300-5.

11. Fattahi E, Forozanfar M, BagheriHaghighi A. Effect of 3,4 methylendioxy meth amphetamine on hepatocyte and liver enzymes Wistar Rats. J GorganUniv Med Sci. 2013; 14(4): 24-9. [Persian] 
12. Kumar M, Chand R, Shah K. Evidences for growthpromoting and fungicidal effects of low doses of tricyclazole in barley. PlantPhysiolBiochem. 2016; 103 : 176-82. doi: 10.1016/j.plaphy.2016.03.002.

13. Kim WR, Flamm SL, Di Bisceglie AM, Bodenheimer HC. Serum activity of alanine aminotransferase (ALT) as an indicator of health and disease. Hepato. 2008; 47(4): 1363-70. doi: 10.1002/hep.22109.

14. Yang RZ, Park S, Reagan WJ, Goldstein R, Zhong S, Lawton M, et al. Alanine aminotransferase isoenzymes: molecular cloning and quantitative analysis of tissue expression in rats and serum elevation in liver toxicity.Hepato. 2009; 49(2): 598-607. doi: 10.1002/hep.22657.

15. Ali AT, Penny CB, Paiker JE, Niekerk Cv, Smit A, William F, et al. Alkaline phosphatase is involved in the control of adipogenesis in the murine preadipocyte cell line, 3T3-L1. ClinChimActa. 2005; 354(1-2): 101-9.
16. Webber M, Krishnan A, Thomas NG, Cheung BM. Association between serum alkaline phosphatase and $C$ reactive protein in the United States national health and nutrition examination survey 2005-2006. ClinChem Lab Med. 2010; 48(2): 167-73. doi: 10.1515/CCLM.2010.052.

17. Aydin M, Oktar S, Ozkan OV, Alçin E, Oztürk OH, NacarA. Letrozole induces hepatotoxicity without causing oxidative stress: the protective effect of melatonin. GynecolEndocrinol. 2011; 27(4): 209-15. doi: 10.3109/09513590.2010.488769.

18.Somchit N, Norshahida AR, Hasiah AH, Zuraini A, Sulaiman MR, NoordinMM. Hepatotoxicity induced by antifungal drugs itraconazole and fluconazole in rats: a comparative in vivo study. HumExpToxicol. 2004; 23(11): 519-25. 